https://doi.org/10.5817/RPT2021-2-5

\title{
PŘEHLED AKTUÁLNÍ JUDIKATURY II/2021
}

FRANTIŠEK KASL, ANDREJ KRIŠTOFÍK, PAVEL LOUTOCKÝ, JAKUB

MÍŠEK, TEREZA NOVOTNÁ, VERONIKA P̌̌́BAŇ ŽOLNERČÍKOVÁ, ANNA STÁRKOVÁ, JAN SVOBODA, JAKUB VOSTOUPAL

\section{PRÁVO DUŠEVNÍHO VLASTNICTVÍ A AUTORSKÉ PRÁVO ZÁKAZ ,VYTĚŽOVÁNÍ‘ NEBO ,ZUŽITKOVÁNÍ‘ CELÉHO OBSAHU DATABÁZE}

Soud: $\quad$ Soudní dvůr Evropské unie

Věc: $\quad$ C-762/19

Datum: 3. 6.2021

Dostupnost: curia.europa.eu

V původním sporu proti sobě stály dvě lotyšské společnosti provozující vyhledávače nabídek práce na internetu. Společnost CV-online provozuje internetové stránky obsahující databázi nabídek práce, nabídky jsou opatřeny tzv. metatagy pro každou nabídku za účelem správné indexace stránky a lepšího vyhledávání nabídek. ${ }^{1}$ Společnost Melons provozuje internetové stránky, které obsahují vyhledávač nabídek práce z různých jiných internetových stránek a databází, mimo jiné i společnosti CV-online. Při vyhledávání pak tyto stránky přesměrují uživatele na „zdrojovou“ stránku konkrétní nabídky přes hypertextový odkaz. K tomuto vyhledávání používá společnost Melons také metatagy nabídek společnosti CV-online, které se spolu s nabídkami objevují v jejím vyhledávání. ${ }^{2}$

\footnotetext{
Bod 10 anotovaného rozhodnutí.

2 Bod 11 anotovaného rozhodnutí.
} 
Společnost CV-online zažalovala společnost Melons za vytěžování a zužitkování obsahu její databáze nabídek práce k lotyšskému prvoinstančnímu soudu, který této žalobě vyhověl. ${ }^{3}$ Žalovaná se odvolala ke krajskému lotyšskému soudu, který položil soudnímu dvoru následující předběžné otázky: 1) zda je činnost, která spočívá v přesměrování uživatele pomocí odkazu na internetové stránky obsahující zdrojovou databázi, zužitkováním databáze a 2) zda užití metatagů, které nejsou součástí databáze, žalovanou společností je vytěžováním databáze? ${ }^{4}$

Na popisovaný případ spadá Směrnice 96/9/ES ze dne 11. března 1996 o právní ochraně databází (dále jen „směrnice“), konkrétně čl. 7 odst. 2, který uvádí, že „a) ,vytěžováním“ je trvalý nebo dočasný přenos celého obsahu databáze nebo jeho podstatné části na jiný podklad, a to jakýmikoli prostředky nebo jakýmkoli zpưsobem; b) ,zužitkováním‘ je jakýkoli způsob zpř̌stupnění veřjnosti celého obsahu databáze nebo jeho podstatné části rozšiřováním rozmnoženin, pronájmem, spojením on-line nebo jinými způsoby přenosu.“

Soudní dvůr uvádí, že obě otázky je nutné posuzovat společně. ${ }^{5}$ Soudní dvůr nejprve cituje předchozí judikaturu' ${ }^{6}$, dle které se jedná o zužitkování v případě metavyhledáváčů, jestliže metavyhledávč „poskytuje neurčitému počtu koncových uživatelů zařízení umožňující vyhledat údaje obsažené v této databázi a nabizí tak př́stup $k$ obsahu této databáze jiným zpưsobem, než je způsob stanovený pořizovatelem uvedené databáze“, taková činnost pak „zbavuje pořizovatele pưvodní databáze př́jmů, čímž zasahuje do jeho zvláštního práva“.7 Soudní dvo̊r zdůrazňuje, že na situaci nic nemění, je-li metavyhledávač v dotčené věci založený na jiném principu, tedy že nepřekládá v reálném čase vyhledávací dotazy svých uživatelů do podoby kritérií používaných těmito formuláři zdrojových databází, ale místo toho stránky indexuje a jejich kopie uchovává na svých serverech. I v tomto případě totiž splňuje podmínky uvedené v citovaném rozhodnutí Innoweb, navíc

\footnotetext{
Bod 13 anotovaného rozhodnutí.

4 Body 14 a 15 anotovaného rozhodnutí.

5 Bod 20 anotovaného rozhodnutí.

6 Body 40 až 42 rozhodnutí C-202/12, Innoweb.

7 Bod 32 anotovaného rozhodnutí.
} 
ukládáním stránek a jejich zpřístupňováním se dopouští vytěžování a zužitkování databáze, které je dle čl. 7 odst. 1 směrnice zakázáno. ${ }^{8}$ Soudní dvůr dále konstatuje, že je na předkládajícím soudu ověřit, zda v daném případě tyto činnosti představují riziko pro návratnost nákladů na tento vklad obvyklým využíváním dotčené databáze pořizovatele. ${ }^{9}$

Soudní dvůr tedy došel k závěru, že specializovaný vyhledávač na internetu při vyhledávání obsahu databází, který kopíruje a indexuje celou databázi a následně umožňuje jeho uživatelům vyhledávat v této databázi na vlastních internetových stránkách provádí „vytěžování“ a „zužitkovánî“ tohoto obsahu, což může být zakázáno pořizovatelem takové databáze, pokud tyto činnosti působí újmu na jeho vkladu, tedy že představují riziko pro návratnost nákladů na tento vklad obvyklým využíváním dotčené databáze, což přísluší ověřit předkládajícímu soudu.

Autorka: TN

\section{SEEDOVÁNÍ DĚL V DIGITÁLNÍ PODOBĚ JAKO SDĚLOVÁNÍ NOVÉ VEŘEJNOSTI}

Soud: $\quad$ Soudní dvůr Evropské unie

Věc: $\quad$ C-597/19

Datum: $\quad$ 17.6. 2021

Dostupnost: curia.europa.eu

Společnost Mircom, která je majitelkou určitých práv k velkému množství pornografických filmů (produkovaných v USA a Kanadě), zažalovala belgickou společností Telenet BVBA poskytující služby přístupu k internetu. ${ }^{10}$ Část pornografického materiálu byla totiž pirátsky zpřístupněna prostřednictvím torrentư ${ }^{11}$ a společnost Mircom skrze prostředníka sesbírala tisíce IP adres údajných „pirátů“ ${ }^{12}$, načež se dožadovala po společnosti Te-

\footnotetext{
8 Bod 37 anotovaného rozhodnutí.

9 Bod 46 anotovaného rozhodnutí.

10 Bod 2 anotovaného rozhodnutí.

11 Body 2 a 29-30 anotovaného rozhodnutí.

12 Bod 30 anotovaného rozhodnutí.
} 
lenet, aby jí vydala informace vedoucí $\mathrm{k}$ jejich identifikaci. ${ }^{13}$ Společnost Telenet však odmítla. ${ }^{14}$

Prvoinstanční soud pak položil SDEU předběžné otázky týkající se toho, zda musí být stažení a současně další sdílení samostatně nepoužitelného fragmentu souboru považováno za sdělování veřejnosti ve smyslu čl. 3/1 směrnice $2001 / 29^{15}$; zda může osoba vystupující v postavení „trolla autorských práv" ${ }^{\text {“16 }}$ požívat stejná práva, která kapitola II směrnice 2004/48 přiznává autorům nebo držitelům licence; a zda je zmíněné zaznamenávání IP adres ${ }^{17}$ legitimní. ${ }^{18}$

SDEU v odpovědi konstatoval, že nepoužitelnost samotných přenášených segmentů není relevantní, neb se nejedná o části děl, nýbrž o části souboru obsahujícího dílo v digitální podobě. ${ }^{19}$ Pro zpř́stupnění díla nové veřejnosti ve smyslu čl. 3/1 a 2 směrnice 2001/29, pak není nutné, aby uživatel stáhl určitý počet segmentů, ale postačuje, aby bylo dílo zpřístupněno veřejnosti takovým způsobem, který umožňuje přístup z místa a v době dle individuální volby uživatelů. ${ }^{20,21}$ Úmyslné jednání uživatelů BitTorrentu přitom není narušeno automatickou povahou sdílení, neb jsou o této skutečnosti informováni a musí s ní souhlasit. ${ }^{22}$

Na druhou otázku SDEU odpověděl tak, že i osoba, která se soustředí toliko na vymáhání náhrady škod od domnělých porušovatelů, může v zásadě

\footnotetext{
13 Bod 2 anotovaného rozhodnutí.

14 Tamtéž.

15 Což navazuje na rozsudek ze dne 14. června 2017, C-610/15, ECLI:EU:C:2017:456, který se týkal sdělování veřejnosti ve smyslu čl. 3. odst. 1 směrnice 2001/29 správci platformy pro sdílení v rámci sítí peer-to-peer.

16 Tedy osoby, která neužívá práva postoupená autory, nýbrž se jen omezuje na vymáhání náhrady škody od údajných porušovatelů a její obchodní model je tak založen na internetovém pirátství, a nikoliv jeho potírání.

${ }_{17}$ Tedy zásahu do práv zaručených Listinou základních práv Evropské unie, zejména respektování soukromého života a ochrana osobních údajů.

18 Bod 37 anotovaného rozhodnutí.

19 Body 38-44 anotovaného rozhodnutí.

${ }^{20}$ V tomto smyslu viz rozsudek ze dne 7. srpna 2018, Renckhoff, C-161/17, ECLI:EU:C:2018:634, bod 20.

${ }^{21}$ Body 45- 48 a 57-59 anotovaného rozhodnutí.

22 Bod 42 anotovaného rozhodnutí.
} 
využívat opatření stanovená v kapitole II směrnice 2004/48, pokud nejsou její žádosti (včetně žádosti o informace) zneužívající či zřejmě nepřiměrené. $^{23}$

Nakonec SDEU uzavřel, že ani čl. 6/1 první pododstavec písm. f) GDPR $^{24}$, ve spojení s čl. 15/1 směrnice 2002/58 v zásadě nebrání tomu, aby nositel práv či třetí osoba jednající na jeho účet systematicky zaznamenávali IP adresy uživatelů sítí peer-to-peer, jichž bylo využito při činnostech porušujících práva duševního vlastnictví, ani tomu, aby jména a poštovní adresy těchto uživatelů byly sděleny uvedenému nositeli či třetí osobě, pokud jsou takové podněty a žádosti odůvodněné, nezneužívající a přiměřené. ${ }^{25}$

Tento rozsudek představuje další významné rozhodnutí v boji proti pirátskému sdílení. Zvláště však odpověd' na třetí otázku může být vnímána jako riskantní krok, který povede k rozšíření monitorování uživatelů internetu.

Autor: JV

\section{ROZKLAD POČÍTAČOVÉHO PROGRAMU ZA ÚČELEM OPRAVY CHYB}

Soud: $\quad$ Soudní dvůr Evropské unie

Věc: $\quad$ C-13/20

Datum: $\quad$ 6. 10.2021

Dostupnost: curia.europa.eu

V původním sporu figuruje společnost Top System, která dodává software veřejné instituci Selor, která má za úkol provádět nábory zaměstnanců veřejné správy v Belgii. Selor byla dále v řízení nahrazena Belgickým státem. Dodávaný software společnosti Top System, na základě licenční smlouvy se

23 Body 91 - 96 anotovaného rozhodnutí.

24 Nařízení Evropského parlamentu a Rady (EU) 2016/679 ze dne 27. 4. 2016 o ochraně fyzických osob v souvislosti se zpracováním osobních údajů a o volném pohybu těchto údajů a o zrušení směrnice 95/46/ES (obecné nařízení o ochraně osobních údajů).

25 Body 106-110, 112-115 a 130-132 anotovaného rozhodnutí. 
Selor, obsahoval provozní problémy, na jejichž vyřešení se strany neshodly, Selor tedy řešila chyby sama mimo jiné pomocí rozkladu softwaru za účelem deaktivace vadné funkce. ${ }^{26}$

Top System Selor zažalovala za porušení autorských práv společnosti $\mathrm{k}$ dodanému software $\mathrm{k}$ belgickému obchodnímu soudu a žádala také o přiznání náhrady škody. ${ }^{27}$ Věc byla postoupena soudu prvního stupně v Bruselu, který žalobu společnosti v podstatné části zamítl. ${ }^{28}$ Společnost Top System se odvolala k Bruselskému odvolacímu soudu, který položil Soudnímu dvoru dvě předběžné otázky: 1) zda je nabyvatel oprávněn provést rozklad počítačového programu za účelem opravy chyb a 2) zda v případě kladné odpovědi je nutné, aby splnil ostatní podmínky rozkladu uvedené v čl. 6 směrnice ${ }^{29}$

Na popisovaný případ spadá Směrnice Rady 91/250/EHS ze dne 14. května 1991 o právní ochraně počítačových programů (dále jen „směrnice") a to zejména čl. 4 (Úkony podléhající omezení), čl. 5 odst. 1 (Výjimky z úkonů podléhajících omezení) a čl. 6 (Rozklad). ${ }^{30}$

Soudní dvůr se nejprve zabýval první otázkou. Dle systematiky směrnice je rozklad v čl. 6 sice uvedenou výjimkou z čl. 4, který obsahuje seznam výlučných práv, které může výlučně provádět pouze nositel práv a jiná osoba pouze $s$ jeho souhlasem, nicméně dle čl. 6 je tato výjimka aplikovatelná pouze na situaci, kdy je rozklad nezbytný pro získání informací o interoperabilitě nezávisle vytvořeného počítačového programu. $\mathrm{V}$ daném př́ípadě se jednalo o rozklad provedený za účelem opravy chyb. Oprava chyb jako výjimka z výlučných práv dle čl. 4 je poté uvedena v čl. 5 odst. 1 . Tento odstavec obsahuje výčet úkonů, které je možné provést bez souhlasu nositele práv za účelem mimo jiné opravy chyb počítačového programu. Soud argumentuje tím, že systematiku směrnice nelze vykládat $\mathrm{v}$ tom smyslu, že rozklad je povolený pouze za situace dle čl. 6. Nejprve argumentuje tím, že

${ }^{26}$ Body 19 a 20 anotovaného rozhodnutí.

27 Bod 21 anotovaného rozhodnutí.

${ }^{28}$ Bod 22 anotovaného rozhodnutí.

${ }^{29}$ Bod 27 anotovaného rozhodnutí.

30 Tato směrnice byla později nahrazena Směrnicí 2009/24/ES ze dne 23. dubna 2009 o právní ochraně počítačových programů. 
samotný rozklad se skládá z aktivit povolených dle čl. 5 odst. $1 .^{31}$ Zadruhé argumentuje tím, že oba články sledují různý účel, čl. 6 má zajistit interoperabilitu programů a čl. 5 má zajistit užívání programu zpo̊sobem, ke kterému byl vytvořen. Ustanovení o interoperabilitě tedy nemůže narušit ustanovení, které má za cíl zajistit řádné užívání dodávaných programů. ${ }^{32}$ Zatřetí by opačný výklad dle soudu vedl k narušení výslovně přiznaného práva nabyvateli programu provádět opravu chyb, které brání jeho řádnému užití. 33

V souvislosti s tímto soud odpověděl na druhou otázku tak, že rozklad, který je provedený za účelem opravy chyb programu, tedy dle čl. 5 odst. 1 nemusí splňovat podmínky čl. 6, protože tato výjimka má jinou oblast působnosti. Avšak, nabyvatel práv k programu musí splnit podmínku nezbytnosti rozsahu a případně dodržení podmínek stanovených ve smlouvě s nositelem práv $\mathrm{k}$ programu. ${ }^{34}$

Soudní dvůr tedy došel k závěru, že rozklad za účelem opravy chyb počítačového programu je v rámci výjimky čl. 5 odst. 1 povolený, nicméně je nutné splnit podmínku nezbytnosti a případně další podmínky uvedené ve smlouvě mezi nositelem a nabyvatelem práv k počítačovému programu.

Autorka: TN

\section{SOUKROMÍ A OSOBNÍ ÚDAJE}

\section{PŘÍPUSTNOST HROMADNÉHO SLEDOVÁNÍ Z PERSPEKTIVY EVROPSKÉHO SOUDU PRO LIDSKÁ PRÁVA}

Soud: $\quad$ Evropský soud pro lidská práva (Velký senát)

Věc: $\quad 58170 / 13,62322 / 14$ a 24960/15 (Big Brother Watch a ostatní v. Velká Británie)

Datum: 25. 5. 2021

Dostupnost: hudoc.echr.coe.int

31 Bod 42 anotovaného rozhodnutí.

32 Body 49 a 50 anotovaného rozhodnutí.

33 Bod 51 anotovaného rozhodnutí.

34 Body 55 a 56 anotovaného rozhodnutí. 
Význam tohoto obsáhlého rozhodnutí Velkého senátu ESLP pro budoucí posuzování přípustnosti a přiměřenosti nástrojů hromadného sledování bude bezpochyby značný, jelikož se jedná o první konečné rozhodnutí ELSP ve věci zaměřené na mezinárodní sdílení zpravodajských informací a režim hromadného sledování. Předmětem sporu byly aktivity zpravodajských služeb Velké Británie při sledování a zachycování elektronické komunikace, tak jak vyplynuly z dokumentů vynesených v roce 2013 na světlo Edwardem Snowdenem. ${ }^{35}$ Stěžovatelé ve všech třech případech namítali porušení základních práv zaručených články 8 a 10 Evropské úmluvy o ochraně lidských práv, tedy práva na respektování soukromého a rodinného života a práva na svobodu projevu.

Posouzením věci ze strany ESLP předcházel poměrně složitý procesní vývoj těchto tří později spojených případů. ${ }^{36}$ Anotované rozhodnutí v rámci výčtu relevantní národní právní úpravy a dalších podkladů, které byly přezkoumávány, poskytuje shrnující vhled do systematiky legitimizačního právního rámce i vlastního fungování hromadného sledování ze strany zpravodajských služeb Velké Británie. ${ }^{37}$ Ten je následován výstižným přehledem relevantních ustanovení mezinárodních úmluv, unijního práva a dosavadní judikatury Soudního dvora Evropské unie. ${ }^{38}$ Je též poskytnut přehled situace v ostatních státech, které jsou stranou Úmluvy, ${ }^{39}$ jakož i ve Spojených státech amerických. ${ }^{40}$ Již díky tomu lze anotované rozhodnutí považovat za hodnotný referenční materiál $\mathrm{v}$ rámci předmětné problematiky.

\footnotetext{
35 Body 12 a 13 anotovaného rozhodnutí.

36 Body 26-60 anotovaného rozhodnutí.

37 Body 61-190 anotovaného rozhodnutí.

38 Je poskytnuto shrnutí rozhodnutí SDEU ve věcech Digital Rights Ireland, ECLI:EU:C:2014:238 (body 209-213 anotovaného rozhodnutí); Tele2 Sverige, ECLI:EU:C:2016:970 (body 214-219 anotovaného rozhodnutí); Ministerio Fiscal, ECLI:EU:C:2018:788 (body 220-222 anotovaného rozhodnutí); Schrems, ECLI:EU:C:2015:650 (body 223-227 anotovaného rozhodnutí); Schrems II, ECLI:EU:C:2020:559 (body 228-234 anotovaného rozhodnutí); Privacy International, ECLI:EU:C:2020:790, a La Quadrature du Net, ECLI:EU:C:2020:791 (body 235-241 anotovaného rozhodnutí).

39 Body 242-260 anotovaného rozhodnutí.

40 Body 261-265 anotovaného rozhodnutí.
} 
Ve výsledku směřovaly stížnosti na tři režimy hromadného sledování: režim hromadného uchovávání komunikace podle čl. 8(4) RIPA ${ }^{41}$; režim přebírání zpravodajských informací od zahraničních zpravodajských služeb; a režim získávání komunikačních metadat od poskytovatelů služeb elektronických komunikací. ${ }^{42}$

Tyto stížnosti byly posouzeny senátem ESLP, který rozhodl v září 2018. Přihlížel přitom k právnímu stavu z listopadu 2017, tedy v době, kdy napadená úprava dle RIPA byla již částečně nahrazena novým režimem IPA. ${ }^{43}$ Přezkum ze strany Velkého senátu $\mathrm{v}$ anotovaném rozhodnutí je z procesních důvodů vázán též k právnímu stavu z listopadu $2017 .{ }^{44}$ Nebyl přitom rozporován a tudíž ani přezkoumáván závěr senátu, že Investigatory Powers Tribunal ustanovený IPA je účinným prostředkem právní ochrany a že $\mathrm{v}$ rámci vnitrostátního přezkumu před podáním stížnosti došlo $\mathrm{k}$ vyčerpání všech dostupných prostředků. ${ }^{45}$

Při posuzování režimu hromadného uchovávání komunikace ${ }^{46}$ dospěl Velký senát k závěru, že se jedná o klíčový nástroj pro identifikaci hrozeb pro národní bezpečnost, ${ }^{47}$ který však má značný potenciál zneužití vedoucí k zásahu do práva na respektování soukromého a rodinného života. ${ }^{48}$ V rámci bilancování pak Velký senát ESLP přistoupil k poněkud formalistickému vyhodnocení přiměřenosti zákonných záruk úpravy nasazení a mantinelů tohoto nástroje, které byly formulovány vưči (dnes již neplatné) úpravě čl. 8(4) RIPA, která byla shledána za nedostatečnou, ovšem $s$ nepřímou indikací, že tento závěr nemusí být přenositelný na novou

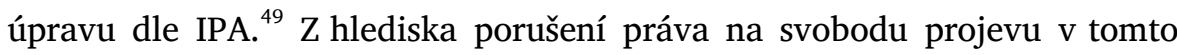

\footnotetext{
$41 \mathrm{Tj}$. Regulation of Investigatory Powers Act z roku 2000.

42 Bod 266 anotovaného rozhodnutí.

43 Tj. Investigatory Powers Act z roku 2016.

44 Bod 270 anotovaného rozhodnutí.

45 Bod 271 anotovaného rozhodnutí.

46 Body 272-427 anotovaného rozhodnutí.

47 Bod 424 anotovaného rozhodnutí.

48 Bod 425 anotovaného rozhodnutí.

49 Body 425-427 anotovaného rozhodnutí.
} 
režimu ${ }^{50}$ pak Velký senát vyhodnotil, že nedostatky identifikované výše, vedoucí k závěru o porušení článku 8 , indikují souběžné porušení článku 10 Úmluvy. ${ }^{51}$

Druhým posuzovaným režimem bylo přebírání zpravodajských informací od zahraničních zpravodajských služeb. Při vyhodnocení souladu s článkem 8 Úmluvy ${ }^{52}$ Velký senát u tohoto režimu porušení neshledal. ${ }^{53}$ Porušení článku 10 Úmluvy nebylo podrobněji analyzováno z procesních důvodů. $^{54}$

Třetím režimem, jehož přípustností se Velký senát zabýval, bylo získávání komunikačních metadat od poskytovatelů služeb elektronických komunikací. ${ }^{55}$ Zde byl nesoulad s články 8 a 10 Úmluvy dovozen již senátem a Velký senát neshledal důvod pro přehodnocení tohoto závěru. ${ }^{56}$

Přestože Velký senát dovodil porušení článků 8 a 10 ve významné části posuzovaných aktivit, výsledným signálem anotovaného rozhodnutí je přijetí hromadného sledování ze strany ESLP jako v principu přípustného a proporcionálního nástroje pro dosahování cílů národní bezpečnosti, za předpokladu zajištění přiměřených záruk a opatření. ${ }^{57}$ Je přitom zjevný důraz na procesní, nikoliv obsahové dosažení těchto záruk. Skrze naplnění vytyčených požadavků ${ }^{58}$ je předpokládáno naplnění přiměřenosti, funkcionality a účinnosti mantinelů zachovávajících práva zakotvená v Úmluvě. Tento

\footnotetext{
50 Body 428-458 anotovaného rozhodnutí.

51 Bod 458 anotovaného rozhodnutí.

52 Body 459-514 anotovaného rozhodnutí.

53 Bod 514 anotovaného rozhodnutí.

54 Body 515-516 anotovaného rozhodnutí.

55 Body 517-528 anotovaného rozhodnutí.

56 Body 522 a 528 anotovaného rozhodnutí.

57 Proti tomuto názoru se vyslovit v podstatě pouze soudce Pinto de Albuquerque ve svém odlišném stanovisku v bodech 58-60. Daný signál přitom ESLP dále podpořil závěrem v paralelně vyhlášeném rozhodnutí ve věci Centrum för Rättvisa v. Švédsko, ECLI:CE:ECHR:2021:0525JUD003525208.

58 Jde o osm kritérií vymezených v bodě 361 anotovaného rozhodnutí, která jsou rozšířením šesti kritérií identifikovaných ESLP ve věci Weber a Saravia v. Německo, ECLI:CE:ECHR:2006:0629DEC005493400, bod 95.
} 
postoj ESLP přitom může významně promluvit i do vyjednávání o podobě řady v současné době připravovaných předpisů. ${ }^{59}$

Autor: FK

\section{ONE-STOP-SHOP MECHANISMUS: PRAVOMOC DOTČENÉHO DOZOROVÉHO ÚŘADU ZAHÁJIT SOUDNÍ ŘÍZENÍ V SOUVISLOSTI S PŘESHRANIČNÍM ZPRACOVÁNÍM}

Soud: $\quad$ Soudní dvůr Evropské unie

Věc: $\quad$ C-645/19

Datum: $\quad$ 15. 6. 2021

Dostupnost: curia.europa.eu

Předběžné otázky podal belgický soud druhého stupně, poté co prvoinstanční soud rozhodl $\mathrm{z}$ iniciativy belgického dozorového úřadu o vydání předběžného opatření proti společnostem Facebook Ireland, Facebook Inc. a Facebook Belgium. Jeho cílem bylo ukončit tvrzené nezákonné shromažd’ování a využívání informací o chování belgických uživatelů na internetu, at’ už byli či nebyli majiteli účtu na Facebooku, a to prostřednictvím různých technologií, jako jsou soubory cookies, pluginy nebo pixely.

Předběžné otázky se týkaly pravomocí (vedoucích) dozorových úřadi̊ a mechanismu spolupráce a jednotnosti, zejména možnosti dozorového úřadu zahájit soudní řízení u soudu ve svém členském státě pro porušení GDPR v souvislosti s přeshraničním zpracováním, pokud není vedoucím dozorovým úřadem pro toto přeshraniční zpracování. Svou odpovědí Soudní dvůr potvrdil obecné pravidlo, že každý dozorový úřad je příslušný k plnění úkolů a výkonu pravomocí v souladu s GDPR na území svého členského státu. ${ }^{60}$ Pokud však jde o přeshraniční zpracování, podle mechanismu „jednoho správního místa“ je příslušným dozorový úřad hlavní provozovny nebo jediné provozovny správce nebo zpracovatele, který má působit jako

\footnotetext{
59 Jde především o návrh nařízení Evropského parlamentu a Rady o evropských předávacích a uchovávacích příkazech pro elektronické důkazy v trestních věcech a jednání o druhém dodatkovém protokolu $\mathrm{k}$ Úmluvě rady Evropy o počítačové kriminalitě.

${ }^{60}$ Bod 47 anotovaného rozhodnutí.
} 
vedoucí dozorový úřad pro přeshraniční zpracování prováděné tímto správcem nebo zpracovatelem. ${ }^{61}$ Soudní dvůr následně konstatoval, že $\mathrm{z}$ tohoto pravidla existují dvě výjimky stanovující příslušnost ostatních dozorových úřadů $\mathrm{k}$ př̌ijetí rozhodnutí $\mathrm{v}$ případě přeshraničního zpracování, a to včetně předběžného. ${ }^{62 \cdot 63}$

Podle Soudního dvora podání žaloby k vnitrostátnímu soudu podle čl. 58 odst. 5 nařízení GDPR nelze vyloučit, pokud není poskytnuta vzájemná pomoc, tak jak tomu ostatně bylo i v tomto konkrétním případě, kdy vedoucí irský dozorový úřad na belgickou žádost o vzájemnou pomoc nereagoval. ${ }^{64}$ Dozorový úřad pak může na svém území přijmout předběžná opatření (čl. 61 odst. 8 GDPR), a pokud se domnívá, že je naléhavě nutné přijmout konečné závazné rozhodnutí, může požádat sbor o vydání naléhavého stanoviska nebo naléhavého rozhodnutí (čl. 66 odst. 2 GDPR). Dále může dozorový úřad požádat Evropský sbor pro ochranu osobních údajů (EDPB) o stanovisko $\mathrm{k}$ jakékoli záležitosti s obecnou působností nebo k záležitosti, která má účinky ve více než jednom členském státě, v souladu s čl. 64 odst. 2 GDPR. Po přijetí takového stanoviska nebo takového rozhodnutí a za předpokladu, že je EDPB po zohlednění všech relevantních okolností schválí, musí být dotčený dozorový úřad schopen přijmout nezbytná opatření k zajištění souladu s pravidly ochrany práv fyzických osob, pokud jde o zpracování osobních údajů obsaženými v GDPR, a za tímto účelem vykonávat pravomoc svěřenou mu čl. 58 odst. 5 GDPR. ${ }^{65}$

Autorka: AS

\section{PODMÍNKY PRO UDĚLENÍ POKUTY PŘI PORUŠENÍ BEZPEČNOSTI OSOBNÍCH ÚDAJŮ}

Soud:

Nejvyšší správní soud

Věc:

1 As 238/2021 - 33

\footnotetext{
${ }^{61}$ Bod 50 anotovaného rozhodnutí.

${ }^{62}$ Viz čl. 56, odst. 2 a 66 GDPR.

63 Bod 63 anotovaného rozhodnutí.

${ }^{64}$ Bod 73 anotovaného rozhodnutí.

${ }^{65}$ Bod 71 anotovaného rozhodnutí.
} 
Datum: $\quad$ 11. 11. 2021

Dostupnost: nssoud.cz

Společnosti Internet Mall, a.s. byla v roce 2018 Úřadem pro ochranu osobních údajů (dále jen „Úřad“) uložena pokuta ve výši 1,5 milionu Kč za nedodržení povinností v souvislosti s únikem osobních údajů přes 700 tisíc uživatelů, následně zveřejněných na serveru ulozto.cz v roce $2017 .^{66}$

Proti rozhodnutí byl neúspěšně podán rozklad a následná správní žaloba byla zamítnuta Městským soudem v Praze dne 24. 6. 2021. Ve zdůvodnění městský soud uvedl, že skutková podstata přestupku je naplněna již nepřijetím nezbytných opatření, přičemž skutečnost, že příslušné rozsáhlé porušení bezpečnosti nebylo detekováno ani po odcizení kompromitovaných údajů, jen vede k závěru, že přijatá opatření nemohla být dostatečně kvalitní. Dále dovodil, že Úřad nemusel ve svém rozhodnutí komentovat jednotlivá přijatá opatření a jejich dostatečnost, jelikož je na správci, aby zvolil vhodný soubor opatření a rozhodný pro posuzování je pouze jejich výsledný účinek, který byl Úřadem vyhodnocen za nedostatečný. ${ }^{67}$

Kasační stížnost směřovala proti názoru městského soudu, že se jedná o přestupek konstruovaný jako odpovědnost za následek. Stěžovatelka namítala, že $\mathrm{v}$ této logice by byla opatření přijatelná pouze $\mathrm{v}$ případě, pokud by se o úniku dat dozvěděla ihned, což je výkladový přístup, který je v rozporu s textem zákona a úmyslem zákonodárce. ${ }^{68}$ Úřad a př́ipadně soud se tedy měl zabývat povahou přijatých opatření, nikoliv skutečností, zda se podařilo uchránit osobní údaje či nikoliv. ${ }^{69}$

Úřad ve svém vyjádření potvrdil svůj předchozí názor, že se jedná o ohrožovací delikt, u kterého pro vznik odpovědnosti postačuje potencialita ohrožení chráněného zájmu. ${ }^{70}$ Odhalení úniku údajů až na základě jejich

\footnotetext{
${ }^{66}$ Bod 2 anotovaného rozhodnutí.

67 Bod 6 anotovaného rozhodnutí.

68 Bod 11 anotovaného rozhodnutí.

69 Body 11-13 anotovaného rozhodnutí.

70 Bod 16 anotovaného rozhodnutí.
} 
zveřejnění s odstupem několika let dle jeho názoru prokazuje, že přijatá opatření byla jako celek neúčinná. ${ }^{71}$

Nejvyšší správní soud prvně shledal kasační stížnost za přípustnou a následně za důvodnou. Částečně se přitom odkázal již na svou předchozí judikaturu k problematice. ${ }^{72} \mathrm{~S}$ kvalifikací městského soudu se ztotožnil toliko v rozsahu, že pro vznik odpovědnosti za přestupek postačuje ohrožení bezpečnosti osobních údajů. Únik osobních údajů však bez dalšího nezakládá závěr, že př́íslušný správce či zpracovatel jednal v rozporu se svými povinnostmi. ${ }^{73} \mathrm{~S}$ odkazem na své předchozí závěry $\mathrm{v}$ podobné věci ${ }^{74}$ upozornil na potřebu vyvarovat se výkladu kladoucího absolutní požadavky na zabezpečení osobních údajů. Úřadu bylo vytknuto, že se ve svém rozhodnutí nezbýval ani kvalitou přijatých opatření, ani způsobem, jakým k úniku dat došlo. ${ }^{75}$ Nejvyšší správní soud proto zrušil jak rozsudek městského soudu, tak rozhodnutí Úřadu a vrátil věc $\mathrm{k}$ dalšímu řízení. $\mathrm{V}$ tom nepředjímá výsledek, ale uložil Úřadu, aby „zohlednil všechna stěžovatelem přjiatá opatření a zabýval se tím, jestli byla s ohledem na dostupnou úroveň ochrany $v$ rozhodném období, charakter činnosti stěžovatele a rozsah jím zpracovávaných údajů dostatečná. $V$ této souvislosti by měl přihlédnout také ke kritériím vyplývajícím z evropské úpravy“. ${ }^{76}$

Rozsudek upozorňuje na potřebu zohledňovat u odpovědnosti správce či zpracovatele za únik osobních údajů více než tuto samotnou skutečnost. Pro rozsah pochybení je pak rozhodné, jaký relativní význam bude přisuzován jednotlivým preventivním, detekčním a reaktivním opatřením a jak bude vyhodnocena jejich dostatečnost s ohledem na riziko spojované s příslušnou formou bezpečnostního incidentu.

Autor: FK

\footnotetext{
71 Bod 17 anotovaného rozhodnutí.

72 Viz rozsudky NSS ze dne 10. 5. 2006, č. j. 3 As 21/2005 - 105 a ze dne 30. 1. 2013, č. j. 7 As $150 / 2012-35$.

73 Bod 33 anotovaného rozhodnutí.

74 Viz rozsudek NSS ze dne 27. 6. 2019, č. j. 4 As 140/2019- 27.

75 Bod 35 anotovaného rozhodnutí.

76 Bod 43 anotovaného rozhodnutí.
} 


\title{
3. ELEKTRONICKÉ KOMUNIKACE \& ISP
}

\author{
K MOMENTU DORUČENIA ELEKTRONICKEJ SPRÁVY \\ Soud: $\quad$ Ústavní soud České republiky \\ Věc: $\quad$ Pl. ÚS 23/20 \\ Datum: $\quad$ 18. 5. 2021 \\ Dostupnost: nalus.usoud.cz
}

Mestský súd v Prahe podal návrh na vyslovenie neústavnosti § 82b ods. 3 zákona č. 235/2004 Sb., o dani z přidané hodnoty. K tomu dospel v rámci konania v ktorom navrhovatel', spoločnost’ so sídlom na Slovensku, podala žalobu proti rozhodnutiu Odvolacieho finančného riaditel'stva, v ktorej namietala počiatok plynutia lehoty. Finančný úrad vyzval prostredníctvom elektronickej pošty žalobkyňu k odstráneniu pochybností, na čo včas nereagovala a preto bola jej žiadost̉ o vrátenie dane zamietnutá. Žalobkyňa namieta, že na výzvu reagovala obratom ihned’ po doručení a že lehota uplynula ešte pred doručením správy. Finančný úrad odkazuje na informáciu vo svojom internom systéme, ktorý eviduje čas odoslania, ktorý je zároveň aj momentom doručenia podla napadnutého ustanovenia $(, \ldots . . d o-$ ručením se rozumí odeslání..."). ${ }^{77}$ Mestský súd v Prahe má zato, že takáto situácia je v rozpore s čl. 2 a 4 Listiny a odkazuje sa na konštantnú judikatúru NSS $\mathrm{v}$ otázke elektronického doručovania ${ }^{78,79}$ ako aj na judikatúru ÚS, ktorý z rovnakého dôvodu zrušil $§ \quad 101 \mathrm{~g}$ ods. 5 (Pl. ÚS 32/15) tohto zákona. ${ }^{80}$

Ústavný súd odmieta podobnost’ s ustanovením § 101g ods. 5, nakolko na rozdiel od premeškania výzvy, to zakladalo sankčnú zodpovednost adresáta. $^{81} \mathrm{Z}$ rovnakého dôvodu odmietol aj námietku Mestského súdu

\footnotetext{
77 Bod 4 anotovaného rozhodnutí.

78 Viz např. 7 Azs 113/2015-32.

79 Bod 8 anotovaného rozhodnutí.

80 Bod 7 anotovaného rozhodnutí

81 Bod 36 anotovaného rozhodnutí.
} 
v Prahe, že uvedené ustanovenie porušuje čl. 2 a 4 Listiny. ${ }^{82}$ ÚS sa d'alej zaoberal možnostou, že aplikácia záverov rozhodnutia Pl. ÚS 32/15 (,...že e-mail nemá jako způsob doručení dostatečnou spolehlivost, aby prokazatelně zaručil, že písemnost bude doručena adresátovi $v$ okamžiku samotného odeslání...") na tento prípad by mohla vieste k porušeniu iných ústavou zaručených práv. ${ }^{83}$

ÚS má zato, že zhora opísaným postupom dochádza k porušeniu materiálneho prístupu $\mathrm{k}$ doručovaniu, ktorý má zaistit možnost’ subjektu oboznámit sa s tím, čo od neho bude vyžadované $\mathrm{v}$ rámci vrchnostenského daňového konania a teda $\mathrm{k}$ porušeniu práv zakotvených $\mathrm{v}$ čl. 2 Listiny. ${ }^{84}$ Možnost̉ oboznámit sa s obsahom aktov daňových orgánov zároveň ÚS považuje za súčast právnej istoty, potažmo potom právneho štátu, preto je postup finančného úradu $\mathrm{v}$ rozpore s článkom 1 ods. 1 Ústavy. ${ }^{85} \mathrm{~V}$ neposlednej rade ÚS odkazuje na to, že materiálny prístup $\mathrm{k}$ doručovaniu spadá po princíp rovnosti zbraní a teda jeho odopretie je narušením práv zakotvených v článku $36{ }^{86}$

Na argument vlády, ktorá bola vedlajším účastníkom konania, že moment odoslania bol zvolený ako jediný zaručene preukázatel'ný moment komunikácie, ÚS uvádza že nie je dôvod prečo tento moment nemôže byt počiatkom plynutia lehoty, ktorej uplynutie zakladá fikciu doručenie, rovnako ako je tomu pri dátových schránkach, prípadne že existuje množstvo riešení tejto situácie, tak aby nedochádzalo k porušovaniu zhora uvedených práv priskorím zakladaním fikcie doručenia. ${ }^{87} \mathrm{Z}$ týchto dôvodu sa nepodarilo dokázat, že sa jedná o nevyhnutný zásah v zmyslu testu proporcionality a ÚS zhladáva $\S 82$ ods. 3 veta tretia zákona ako odporujúce čl. 36 Listiny, čl. 2 ods. 2 Listiny a článku 1 ods. 1 Ústavy.

Autor: AK

\footnotetext{
82 Bod 37 anotovaného rozhodnutí.

83 Bod 44 anotovaného rozhodnutí.

84 Bod 45 anotovaného rozhodnutí.

85 Tamtéž.

86 Bod 46 anotovaného rozhodnutí.

87 Bod 50 anotovaného rozhodnutí.
} 


\section{ODPOVĚDNOST ONLINE PLATFOREM ZA NELICENCOVANÝ OBSAH}

Soud: $\quad$ Soudní dvůr Evropské unie

Věc: $\quad$ C-682/18 a C-683/18

Datum: $\quad$ 22. 6. 2021

Dostupnost: curia.europa.eu

$\mathrm{V}$ rámci tohoto soudního rozhodnutí byly řešeny dvě spojené věci. V prvním případě došlo k neoprávněnému nahrání děl umělkyně Sarah Birmingham na platformu YouTube. Producent (Frank Peterson) požadoval po společnosti Google (která kontaktovala platformu YouTube) stažení těchto děl, což se stalo, stejný obsah byl na platformu nahrán ale opět po týdnu. Producent následně podal proti společnostem Google a YouTube u německého soudu žalobu na zdržení se jednání a žalobu směřující $\mathrm{k}$ tomu, aby byly poskytnuty informace a byla určena povinnost žalovaných společností zaplatit náhradu škody. ${ }^{88} \mathrm{~V}$ druhé věci společnost Elsevier žalovala společnost Cyando, která provozuje platformu umožňující nahrávání obsahu. Na tuto platformu byla bez souhlasu nahrána tři díla, ke kterým měla výhradní práva společnost Elsevier. Ta podala žalobu $\mathrm{k}$ jinému německému soudu a domáhala se obdobného jako v prvním případě. ${ }^{89}$

Spolkový soudní dvůr v rámci dovolání postupně shledal, že je podstatné se zabývat tím, jestli jednání provozovatelů platforem pro ukládání a sdílení obsahu představuje sdělování díla veřejnosti ve smyslu čl. 3 odst. 1 směrnice o autorském právu a jestli pak daná činnost spadne do působnosti čl. 14 odst. 1 směrnice o elektronickém obchodu a na provozovatele se tak může vztahovat zproštění odpovědnosti, pokud jde o informace uložené na platformě. ${ }^{90}$

Byly tak postupně formulovány zejména následující předběžné otázky:

\footnotetext{
88 Bod 24 anotovaného rozhodnutí.

89 Bod 55 anotovaného rozhodnutí.

90 Bod 34 a násl. anotovaného rozhodnutí.
} 
1) Jedná se o sdělování díla veřejnosti, pokud veřejně zpřístupněný obsah porušuje autorská práva, ale provozovatel si není výslovně vědom dostupnosti takového obsahu (případně po uvědomění obsah neprodleně odstraní)?

2) Pokud ne, může se na provozovatele vztahovat zproštění odpovědnosti dle čl. 14 odst. 1 směrnice o elektronickém obchodu?

3) Musí se pak účinné seznámení se s protiprávní činností nebo informací nebo vědomost o skutečnostech či okolnostech, z nichž je protiprávní činnost nebo informace zjevná podle čl. 14 odst. 1 směrnice, týkat konkrétních protiprávních činností nebo informací?

4) „V př́padě záporné odpovědi na první i druhou otázku: Má být provozovatel [platformy pro ukládání a sdílení souborů] za okolností popsaných v první otázce považován za porušovatele práv ve smyslu čl. 11 věty první a článku 13 směrnice [o dodržování práv]?". Pokud ano, lze pak uložit porušovateli povinnost k náhradě vzniklé škody?

SDEU se k vyjádřil v tom smyslu, že ke sdělování díla veřejnosti nedochází v případě, „že by nad rámec pouhého zpřístupnění [provozovatel] přispíval ke zpř́stupnění takových obsahů veřejnosti v rozporu s autorským právem“. ${ }^{91}$ Zde je tak podstatný úmysl platformy k takovému zveřejnění. Přispíváním se pak myslí to, že (i) provozovatel věděl o nezákonné dostupnosti obsahu, (ii) upustil od využití vhodných technologických opatření k eliminaci takového chování a (iii) poskytuje nástroje k nezákonnému sdílení či takové sdílení úmyslně podporuje. Ke zproštění odpovědnosti pak dojde, pokud platforma nemá aktivní roli, a tak není možné konstatovat, „že obsahy nahrané na svou platformu zná nebo kontroluje. “92 To dále znamená, že provozovatel si musí být vědom konkrétních porušení. ${ }^{93}$ Podle vnitrostátního práva ale taková nevědomost neznamená, že proti provozovateli nemůže nositel práv podat žalobu k náhradě škody (případně ve chvíli, kdy poskytovatel nereagoval adekvátně na oznámení o odstranění

\footnotetext{
91 Bod 102 anotovaného rozhodnutí.

92 Bod 117 anotovaného rozhodnutí.

93 Bod 118 anotovaného rozhodnutí.
} 
nelegálního obsahu). K poslední otázce se soud nevyjádřil, jelikož na první dvě otázky odpověděl kladně.

Závěrem je ale důležité upozornit na to, že výše řečené nebude již relevantní pro autorskoprávně chráněný obsah ve chvíli, kdy dojde k implementaci čl. 17 směrnice $\mathrm{DSM}^{94}$, který stanovuje, že platforma nebude odpovědna za takový obsah nahraný uživatelem jen ve chvíli, kdy vynaložila veškeré úsilí k zisku souhlasu od držitele, urychleně odstranila obsah, zabránila budoucímu nahrávání takového obsahu (sic!) a zajistila nedostupnost konkrétního obsahu, pro který nositelé práv poskytli dané a nezbytné informace. Toto rozhodnutí je tak do budoucna zejména vodítkem pro posuzování obsahu, který není chráněn autorským právem (např. otázka pomluvy atp.).

Autor: PL

\section{HELLSHARE A NEKALOSOUTĚŽNÍ JEDNÁNí}

Soud: $\quad$ Nejvyšší soud

Věc: $\quad 23$ Cdo $2793 / 2020$

Datum: $\quad 31.8 .2021$

Dostupnost: nsoud.cz

Česká národní skupina Mezinárodní federace hudebního průmyslu (dále jako „žalobkyně“) se domáhala ochrany před nekalosoutěžním jednáním společností, které stojí za několika populárními úložišti (mj. HellShare a HellSpy) určenými ke sdílení souborů mezi koncovými uživateli. ${ }^{95}$ Jejich ekonomický model je dle žalobkyně založený na poplatcích uživatelů za stahování. ${ }^{96}$ Žalovaní tak mají zájem na tom, aby uživatelé nahrávali obsah lákavý97 a podporují tyto „uploadery“ odměnami závisejícími na počtu/ob-

94 Směrnice (EU) 2019/790 ze dne 17. dubna 2019 o autorském právu a právech s ním souvisejících na jednotném digitálním trhu a o změně směrnic 96/9/ES a 2001/29/ES.

95 Bod 2 anotovaného rozhodnutí.

96 Tamtéž.

97 Často se tak bude jednat o obsah svým způsobem vzácný, např. chráněný právy duševního vlastnictví, za který by uživatelé museli jinak zaplatit. 
jemu stažení sdíleného obsahu. ${ }^{98}$ Tím měli žalovaní opustit „bezpečný př́stav". ${ }^{99}$

Městský soud v Praze žalobě částečně vyhověl,${ }^{100}$ Vrchní soud v Praze se ale $s$ jeho názory neztotožnil a zamítl žalobu v celém rozsahu, nebot' neshledal, že by samotné odměňování uživatelů nebo provoz vyhledávače naplňovaly podmínky překročení „bezpečného přístavu“ či znaky nekalosoutěžního jednání. ${ }^{101}$

Nejvyšší soud se tak zabýval otázkou, kam až sahá limitace odpovědnosti poskytovatelů služeb internetové společnosti a zda může ve vytváření podmínek pro sdílení nelegálního obsahu spočívat nekalosoutěžní jednání.

Na danou materii dopadají primárně ustanovení $\S \S 5$ odst. 1 a 9 odst. 1 zákona č. 480/2004 Sb., o některých službách informační společnosti, které stanovují požadavky na obsah a kvalitu poskytované služby včetně podmínek odpovědnostních, a § 2976 zákona č. 89/2012 Sb., občanského zákoníku, tedy generální klauzule nekalé soutěže.

Soud se nejprve zabýval otázkou omezení odpovědnosti poskytovatelů služeb. Připomenul, že v souladu s evropskou judikaturou ${ }^{102}$ se i poskytovatelé v postavení tzv. prostředníku ${ }^{103}$ musí poskytování takových služeb zdržet. ${ }^{104}$ Ustanovení $§ 5$ odst. 1 zákona o některých službách informační společnosti pak odpovědnost poskytovatele „za obsah informací uložených na žádost uživatele“ omezuje, nezbavuje jej ovšem odpovědnosti za jakýkoli další soukromoprávní delikt, ke kterému může v souvislosti s výkonem jeho hospodářské činnosti dojít. ${ }^{105}$ Ochrana „bezpečného př́stavu“ se tak v této

\footnotetext{
98 Tamtéž.

99 Tamtéž.

100 Bod 1 anotovaného rozhodnutí.

101 Body 3 až 9 anotovaného rozhodnutí.

102 Srov. rozsudky Soudního dvora ze dne 12. 7. 2011, ve věci C-324/09, L’Oréal SA a další proti eBay International AG a dalším, a ze dne 7. 7. 2016, ve věci C-494/15, Tommy Hilfiger Licensing LLC a další proti DELTA CENTER a.s.

${ }^{103}$ Tedy těch, jejichž služby jsou využívány třetími osobami k porušování práv duševního vlastnictví ve smyslu čl. 11 směrnice 2004/48/ES.

104 Body 41-45 anotovaného rozhodnutí.

105 Bod 45-47 anotovaného rozhodnutí.
} 
situaci nepoužije. ${ }^{106}$ Nad to dodal, že skutečnost, že poskytovatelé vystupují toliko v pozici „prostredníka“, není překážkou pro aplikaci ustanovení o nekalé soutěži, nebot tato odpovědnost je vystavěna na objektivním principu. ${ }^{107}$ Nekalosoutěžního jednání se tím pádem nedopouští pouze ten, kdo sám soutěž narušuje, ale i ten, kdo vzhledem „k jeho hospodářské činnosti objektivně vytvář́ $v$ rozporu $s$ dobrými mravy soutěže podmínky pro takovéto jednání jiné osoby či z výsledků takového jednání jiného těží s důsledky způsobilými přivodit újmu jiným soutěžitelům či zákazníkưm“ “ ${ }^{108}$ To se uplatní i na poskytovatele služeb informační společnosti ${ }^{109}$, zvláště v případě, kdy soutěžitel nabízí uživatelům odměnu odvíjející se od počtu či rozsahu stahování, aniž by dostatečným způsobem ověřil, že nedochází k porušování práv duševního vlastnictví. ${ }^{110}$ Nejvyšší soud pak ještě dodal, že pokud poskytovatel do výsledků vyhledávání nijak nezasahuje, nemůže být samotný provoz vyhledávače v úložišti považován za nekalosoutěžní jednání jenom proto, že mezi výsledky může být obsah chráněný právy duševního vlastnictví. ${ }^{111} \mathrm{Na}$ základě těchto skutečností shledal dovolání jako důvodné a napadené rozhodnutí zrušil.

Nejvyšší soud tímto rozsudkem značně limitoval dosah „bezpečného př́stavu" a připustil soutěžně-právní alternativu v boji proti nelegálnímu sdílení chráněného obsahu na internetu, a to ještě před implementací směrnice č. 2019/790, ${ }^{112}$ která pravidla „bezpečného př́stavu“ do značné míry limituje.

Autor: JV

\footnotetext{
${ }^{106}$ Bod 52 anotovaného rozhodnutí.

107 Bod 74 anotovaného rozhodnutí.

${ }^{108}$ Bod 80 anotovaného rozhodnutí.

${ }^{109}$ Bod 83 anotovaného rozhodnutí.

${ }^{110}$ Body 95-97 a 100 anotovaného rozhodnutí.

${ }^{111}$ Body 104-106 anotovaného rozhodnutí.

112 Směrnice Evropského parlamentu a Rady (EU) 2019/790 ze dne 17. dubna 2019 o autorském právu a právech s ním souvisejících na jednotném digitálním trhu a o změně směrnic 96/9/ES a 2001/29/ES.
} 


\section{ZAJIŠTĚNÍ PRINCIPU NEUTRALITY PŘI VYUŽÍVÁNÍ ROAMINGU, POSKYTOVÁNÍ NULOVÉHO TARIFU}

Soud: $\quad$ Soudní dvůr Evropské unie

Věc: $\quad$ C-854/19

Datum: $\quad$ 2. 9. 2021

Dostupnost: curia.europa.eu

Vodafone GmnH ve Spolkové republice Německo poskytuje tzv. Vodafone pass. Zákazník může využívat audio, video a další služby partnerských podniků, aniž by spotřebovával objem dat obsažených v základním paušálním tarifu. ${ }^{113}$ Služba platí pouze v tuzemsku (Německu) a nikoliv při roamingu. ${ }^{114}$

Německý Správní soud v Kolíně nad Rýnem podal předběžnou otázku ve sporu Vodafone GmbH proti Bundesrepublik Deutschland v rámci sporu o rozhodnutí uložené německou agenturou; ${ }^{115}$ Vodafone měl ukončit omezování služby v zahraničí. ${ }^{116}$ Vodafone proti rozhodnutí dne 11 . prosince 2018 podal žalobu u předkládajícího soudu. ${ }^{117}$

Podstatou soudem předložených předběžných otázek ${ }^{118}$ je, zda omezení tzv. nulového tarifu při roamingu představuje porušení článků $6 \mathrm{a}$ a $6 \mathrm{~b}$ nařízení Evropského parlamentu a Rady (EU) č. 531/2012 ze dne 13. června 2012 o roamingu ve veřejných mobilních komunikačních sítích v Unii ve znění nařízení Evropského parlamentu a Rady (EU) č. 2015/2120 ze dne 25. listopadu 2015 („nařízení o roamingu“).

Nařízení zaručuje uživateli̊m právo na přístup k informacím, obsahu, aplikacím a službám bez diskriminace, poskytovatelům pak povinnost to

\footnotetext{
113 Bod 7 anotovaného rozhodnutí.

${ }^{114}$ Bod 8 anotovaného rozhodnutí.

$115 \mathrm{Tj}$. Spolková agentura pro elektroenergetické sítě, plyn, telekomunikace, poštu, a železnice.

${ }^{116}$ Bod 2 anotovaného rozhodnutí.

117 Bod 11 anotovaného rozhodnutí.

118 Body 6-13 anotovaného rozhodnutí.
} 
zajistit (recitály 6, 8). ${ }^{119}$ Závaznost je dána čl. 3 nařízení, odst. $1-3 .{ }^{120}$ Poskytovatel může přijmout opatření přiměřeného řízení provozu představující určitá omezení. Pokud je smyslem optimalizovat kvalitu sítě (recitál 9). ${ }^{121}$ Čl. 3 odst. 3 nařízení stanoví požadavky přiměřenosti. ${ }^{122}$ Čl. $6 \mathrm{a}$ a $6 \mathrm{~b}$ přibyly do nařízení společně se zrušením roamingových poplatků. Čl. 6a ruší maloobchodní příplatky za roaming, čl. 6b stanoví výjimku pro případ, že omezení má zabránit zneužití služeb.

Soudní dvůr shledává narušení principu neutrality zavedením nulového tarifu (čl. 3 odst. 1-3). Soud připomíná, že smyslem čl. 3 je zajistit rovné a nediskriminační jednání při poskytování služeb přístupu $\mathrm{k}$ internetu ${ }^{123}$ a odkazuje na předchozí rozhodovací činnost. ${ }^{124}$ Pokud je opatření omezující provoz založeno na obchodních cílech, pak není v souladu s čl. 3 odst. 3 nařízení. ${ }^{125}$ Soud rozhodl, že omezení používání roamingu z důvodu aktivace nulového tarifu je neslučitelné s povinnostmi v čl. 3 odst. 3 nařízení. ${ }^{126}$

Spor z roku 2018 je připomenutím změn v unijní úpravě, kterými byly zrušeny roamingové poplatky s účinností od 2017. Přidání čl. 6a a 6b do nařízení mohlo být pro soud matoucí, když se při položení předběžné otázky soustředil právě na tato ustanovení a nikoliv na obecný princip neutrality dle čl. 3 nařízení.

Autorka: VPŽ

\section{ZJEDNOTENIE JUDIKATÚRY V OTÁZKACH MOMENTU DORUČENIA ELEKTRONICKEJ SPRÁVY}

Soud: Ústavní soud České republiky

Věc: $\quad$ Pl. ÚS-st. 53/21

\footnotetext{
${ }^{119}$ Bod 3 anotovaného rozhodnutí.

${ }^{120}$ Bod 5 anotovaného rozhodnutí.

${ }^{121}$ Bod 3 anotovaného rozhodnutí.

${ }^{122}$ Bod 5 anotovaného rozhodnutí.

${ }^{123}$ Body 21 a 22 anotovaného rozhodnutí.

${ }^{124}$ Rozsudek ze dne 15. záŕí 2020, Telenorr Magyarország, C-807/18 a C-39/19, ECLI:EU:C:2020:708, body 23-28.

${ }^{125}$ Bod 25 anotovaného rozhodnutí.

${ }^{126}$ Právní věta anotovaného rozhodnutí.
} 
Datum: $\quad$ 7. 9. 2021

Dostupnost: nalus.usoud.cz

Stažovatel'ova brojili proti zamietnutiu žiadosti o doplnenie rozsudku Mestského súdu v Prahe blanketnou kasačnou stažnostou pred NSS. Stažnost’ bola zamietnutá pre premeškanie lehoty na doplnenie, ktorá bola súdu doručená dve hodiny a 46 minút po jej uplynutí prostredníctvom elektronickej pošty. Staž̌ovatel' s odkazom na čas elektronického podpisu ako aj s odkazom na čas jej odoslania, ktorý bol 16 minút pred uplynutím lehoty namieta porušenie jeho práva na spravodlivý proces. NSS namieta, že relevantný je čas kedy správa prišla na jeho servery, nakol'ko odkazované informácie sa riadia časom nastaveným na zariadení a nie reálnym časom. $^{127}$

Prvý senát ÚS dospel k záveru že je nutné zjednotit, stávajúcu judikatúru ÚS v otázke elektronického doručovania a preto bola celá vec postúpená plénu ÚS. ${ }^{128}$

Prvý senát chce prekonat’ stávajúci nález II. ÚS 2560/13, podl’a ktorého sa má prihliadat najmä na vecnú a meritórnu stránku doručovania, že súd sa s doručenou poštou neoboznamuje skôr ako na začiatku pracovnej doby. Podanie učinené elektronickou poštou by malo byt akceptované aj ak bolo učinené len niekol'ko sekúnd pred uplynutím lehoty a súdu došlo až po jej uplynutí, v opačnom prípade by sa jednalo o prílišný formalizmus. ${ }^{129}$ Citovaný nález nezhl’adal žiadne materiálne následky prijímania takýchto ,fakticky oneskorených“ podaní.

ÚS poukazuje na rozpor tohto nálezu jednako s judikatúrou NSS ako ja s inou judikatúrou ÚS, týkajúcou sa iných spôsobov doručovania, najmä potom telefaxu. ${ }^{130}$ ÚS prekonávaný nález II. ÚS 2560/13 kritizuje za nezohl'adnenie povinne zriadených dátových schránok advokátov, ktorá odstraňujú nejasnosti doby odoslania, resp. problém oneskoreného

\footnotetext{
${ }^{127}$ Bod 10 anotovaného rozhodnutí.

${ }^{128}$ Bod 14 anotovaného rozhodnutí.

${ }^{129}$ Body 16 a 17 anotovaného rozhodnutí.

${ }^{130}$ Body 21 a 22 anotovaného rozhodnutí.
} 
doručenia. Ďalej tiež kritizuje absolutizáciu práva na spravodlivý proces, ktorý jednako odstraňuje právnu istotu lehôt ako aj odporuje zásade vigilantibus iura scripta sunt. ${ }^{131}$ ÚS s odkazom na judikatúru ESL'P uvádza, že sa jedná o konflikt prepätého formalizmu a právnej istoty. ${ }^{132}$

Plénum sa d’alej zaoberá rozdielom v spôsoboch doručovania, teda rozdielom medzi privilegovaným spôsobom doručenia, bežným a iným spôsobom. ${ }^{133}$ Privilegovaný spôsob doručovania, teda doručenie prostredníctvom držatela poštovej licencie je spôsob ktorý je upravený zákonom, podobne ako doručenie orgánom $\mathrm{k}$ tomu povinným je zákonom garantované doručenie predanej zásielky. ${ }^{134}$ Doručenie prostredníctvom služby elektronickej pošty, ktorá je predaním $\mathrm{k}$ doručeniu tretou osobou a doručenie sa riadi nanajvýš súkromnoprávnym zmluvným ujednaním medzi stranami. ${ }^{135}$ Ďalej súd poukazuje na skutočnost', že medzi neprivilegované spôsoby patrí aj osobné podanie, ktoré musí prebehnút na podatel’ni v otváracích hodinách, teda podatel' nemá $\mathrm{v}$ takom prípade $\mathrm{k}$ dispozícii celú lehotu, ktorá zpravidla uplynie polnocou a nie pracovnými hodinami súdu.

Súd d’alej kritizuje možné technické problémy spojené s prekonávaným rozsudkom a okrem skutočnosti, že súd je schopný overit len informáciu kedy dorazila správa na jeho servery, poukazuje na retazec server ktorými elektronická pošta prechádza, pričom súd je zodpovedný iba za posledný zo serverov $\mathrm{v}$ tomto retazci a nemožno mu pričítat výpadok niektorého iného $\mathrm{z}$ týchto serverov. ${ }^{136}$

Súd záverom ešte dodáva, že obmedzenie je primerané, nakolko existuje celá rada alternatívnych spôsobov doručovania, ako napríklad dátové schránky, ktoré umožňujú účastníkom využit komfortu elektronickej pošty, ako aj celej lehoty na podanie. ${ }^{137}$ Súd v tomto odstavci však upozorňuje že kvalita doručenia prostredníctvom datovej schránky nie je zákonom zaru-

\footnotetext{
${ }^{131}$ Bod 23 anotovaného rozhodnutí.

132 Bod 30 anotovaného rozhodnutí.

133 Bod 51 anotovaného rozhodnutí.

134 Body 52 a 55 anotovaného rozhodnutí.

${ }^{135}$ Body 57 anotovaného rozhodnutí.

${ }^{136}$ Body 58 anotovaného rozhodnutí.

${ }^{137}$ Bod 62 anotovaného rozhodnutí.
} 
čená, s čím nesúhlasí prvé odlišné stanovisko, v ktorom sudca spravodaj prejavuje názor, že prevádzkovatel' datových schránok je držatel’om poštovej licencie a preto by podanie datovými schránkami malo mat’ privilegované postavenie. Súd v závere rozsudku nielen zjednocuje judikaturu v otázke doručovania e-mailom ale poskytuje návod súdom ako postupovat’ v prípadoch dôkaznej núdze.

Autor: AK

\section{ELEKTRONICKÝ DOKUMENT A FOTOGRAFIE V MOBILNÍM}

\section{TELEFONU}

Soud:

Nejvyšší správní soud

Věc:

1 Afs $369 / 2020-54$

Datum:

20. 10. 2021

Dostupnost:

nssoud.cz

Příslušníci celního úřadu na dálnici D1 prováděli kontrolu potřebných oprávnění při přepravě výrobků. U jednoho dopravního prostředku zajistili pivo v objemu více než 640 litrů ve vlastnictví žalobkyně, ze strany řidiče dopravního prostředku dle jejich tvrzení však nebyl předložen prríslušný doklad - převodky (dle § 5 zákona č. 353/2003 Sb., o spotřebních daních), jelikož toto množství přesahovalo osobní spotřebu. Nutno podotknout, že při kontrole byly předloženy kopie převodek v elektronické podobě, které byly celníkům v průběhu místního šetření ukázány v mobilním telefonu. ${ }^{138}$

Proti rozhodnutí se žalobkyně bránila u Městského soudu v Praze, který případ vrátil k posouzení zpět příslušnému celnímu úřadu, jelikož se neztotožnil s jím učiněnými formalistickými závěry. Celní úřad namítal, že nezpochybňoval, že jednatel žalobkyně v průběhu místního šetření ukázal v mobilním telefonu kopie převodek. „Tím, že jednatel žalobkyně „doklady o převodu piva“ ukázal prostřednictvím mobilního telefonu správci daně na místě pokračování kontroly, však neprokázal, že by tyto doklady dopravoval

\footnotetext{
${ }^{138}$ Bod 4 anotovaného rozhodnutí.
} 
společně se zajištěnými vybranými výrobky $v$ každém okamžiku jejich dopravy. “139 Pouze tak osvědčil jejich faktickou existenci. Na základě toho podal celní úřad (žalovaný) kasační stížnost, kterou Nejvyšší správní soud shledal jako př́pustnou.

Nejvyšší správní soud v rozsudku zdůrazňuje, že považuje za zásadní argument, že žalobkyně „měla doložit, „kdy, kde, kým a jakým zpưsobem byly kopie převodek I, II a III ve formě fotografií vyhotoveny a zda provázely přepravu zajištěného piva $v$ každém okamžiku jeho přepravy““ ${ }^{140}$ Zároveň zdůrazňuje, že celní úřad si protiřečí, když tvrdí, že není vyloučena možnost předložit dokumenty $\mathrm{v}$ jiné než listinné podobě a současně pak ale nepostačuje „doklady o převodu piva“ pouze ukázat správci daně prostrednictvím obrazovky mobilního telefonu, nýbrž je třeba ,doklady o převodu piva' správci daně předložit $v$ materiální - listinné podobě ${ }^{\text {“ }}{ }^{141}$ Soud zdůrazňuje, že účelem úpravy je mít možnost při kontrole posoudit, zda byla spotřební daň uhrazena, což lze bezesporu doložit v elektronické podobě. ${ }^{142}$ Dále pak uvádí, že „lpění na listinné podobě dokumentů $v$ situaci, kdy to není pro naplnění účelu právní úpravy nezbytné, je přepjatě formalistické. “143

Nejvyšší správní soud tak shledal kasační stížnost jako nedůvodnou a zdůraznil, že prokázání existence př́slušných dokumentů prostřednictvím mobilního telefonu postačuje pro dané účely. Poměrně jasně tak podtrhuje důležitost nediskriminace elektronického dokumentu jen vzhledem $k$ dané formě.

Autor: PL

\footnotetext{
${ }^{139}$ Bod 7 anotovaného rozhodnutí.

${ }^{140}$ Bod 18 anotovaného rozhodnutí.

141 Tamtéž.

${ }^{142}$ Bod 22 anotovaného rozhodnutí.

143 Bod 24 anotovaného rozhodnutí.
} 


\section{PŘÍSTUP K INFORMACÍM VE VEŘEJNÉ SPRÁVĚ}

\section{VYČÍSLENÍ A ODŮVODNĚNÍ ÚHRADY ZA ŽÁDOST \\ O INFORMACE V REŽIMU MIMOŘÁDNĚ ROZSÁHLÉHO VYHLEDÁVÁNÍ}

Soud: $\quad$ Nejvyšší správní soud

Věc: $\quad 1$ As $281 / 2020$

Datum: $\quad$ 5. 2. 2021

Dostupnost: nssoud.cz

Žalobce podal dne 26. 7. 2017 žádost o poskytnutí informací dle zákona č. 106/1999 Sb. (dále jen jako „IZ“), týkající se některých informací (např. počet podnětů ve věcech tvrzeného zneužití dominantního postavení) o podnětech přijatých Úřadem pro ochranu hospodářské soutěže (dále jako „žalovaný“) od dne 1. 1. 2017 do dne vyřízení žádosti. ${ }^{144}$ Žalovaný na žádost odpověděl tak, že přijal v daném období 133 podnětů, zbytek požadavků a specifik, o které žalobce žádal, však podmínil úhradou částky 47481 Kč (tedy téměř 100 hodin práce). ${ }^{145}$

Žalobce proti tomuto podal stížnost, předseda žalovaného však stížnosti nevyhověl a jelikož žalobce částku nezaplatil, žalovaný žádost odložil. ${ }^{146}$ Žalobce pak podal žalobu ke Krajskému soudu v Brně, kde se domáhal zrušení rozhodnutí žalovaného. ${ }^{147}$ Krajský soud předmětné rozhodnutí zrušil, nebot’ z vyčíslení nebyly patrné jednotlivé dílčí úkony, jež je nutné provést $\mathrm{k}$ vyhovění požadavku, toliko celková časová náročnost. ${ }^{148}$ Zároveň upozornil na nedostatečné odůvodnění sazby 238 Kč za každou započatou půlhodinu práce, u níž žalovaný ani nezohlednil reálnost těchto nákladů. ${ }^{149}$ Žalovaný napadl rozsudek kasační stížností.

\footnotetext{
${ }^{144}$ Body 1 a 2 anotovaného rozhodnutí.

145 Body 3 anotovaného rozhodnutí.

146 Tamtéž.

${ }^{147}$ Bod 4 anotovaného rozhodnutí.

${ }^{148}$ Bod 5 anotovaného rozhodnutí.

${ }^{149}$ Body 6-7 anotovaného rozhodnutí.
} 
NSS byl tedy opět postaven před otázku, jak je nutné zdůvodňovat a vyčíslovat úhradu při naplňování žádosti o informace podle IZ, zvláště v režimu mimořádně rozsáhlého vyhledávání. ${ }^{150}$

Na tuto materii dopadají ustanovení $\S 17$ odst. 1 a 3 IZ, které stanovují podmínky pro hrazení nákladů vzniklých v souvislosti s poskytováním informací. Odstavec první limituje výši úhrady a přiznává povinným subjektům možnost požadovat úhradu za mimořádné rozsáhlé vyhledávání informací. Odstavec třetí pak stanovuje podmínky vyčíslení, zejména, že musí být zřejmé, na základě jakých skutečností a jakým způsobem byla výše úhrady vyčíslena.

NSS v reakci argumenty stěžovatele (žalovaného) upozornil, že jakékoliv omezení či podmiňování (tedy např. právě úplatnost) práva na informace jakožto jednoho ze základních kamenů demokracie podléhá restriktivnímu výkladu. ${ }^{151}$ Finanční kompenzace nemá sloužit $\mathrm{k}$ tomu, aby představovala překážku svobodnému přístupu k informacím, ale toliko kompenzovala zátěž nad míru obvyklou. ${ }^{152,153}$ Povinný subjekt tak musí odůvodnit, proč nejde o vyhledávání běžné, zvláště, když se jedná o informace potřebné k jeho každodenní činnosti, a konkretizovat nejen relevantní skutečnosti, ale také způsob vyčíslení výše úhrady podle § 17/3 IZ. Tato konkretizace musí být navíc náležitě odi̊vodněna. ${ }^{154}$ NSS zároveň žalovanému vytkl, že nesprávně vycházel při vyčíslování úhrady $\mathrm{z}$ analogického postupu u jiné žádosti žalobce, aniž by reflektoval změnu v požadavku (žalobce již nepožadoval komplexnější informace o případu). ${ }^{155}$ Odmítl pak i způsob vyčíslení, které žalobce provedl na základě průměru osobních nákladů zúčastněných úředníků, nebot nemusí být ani reálné, ani přiměřené. ${ }^{156}$

\footnotetext{
150 Bod 9 anotovaného rozhodnutí.

151 Body 27 a 28 anotovaného rozhodnutí.

152 Srov. rozsudek Nejvyššího správního soudu ze dne 20. 10. 2016, č. j. 5 As 35/2016 - 25.

153 Bod 28 anotovaného rozhodnutí.

154 Body 28-30 a 34-37 anotovaného rozhodnutí.

155 Bod 35 anotovaného rozhodnutí.

${ }^{156}$ Bod 37 anotovaného rozhodnutí.
} 
NSS se tak ztotožnil s názory krajského soudu a kasační stížnost pro nedůvodnost zamítl. ${ }^{157}$

Autor: JV

\section{DALŠÍ UŽITÍ INFORMACÍ VEŘEJNÉHO SEKTORU S OSOBNÍMI ÚDAJI}

Soud: $\quad$ Soudní dvůr Evropské unie

Věc: $\quad$ C-439/19 (Latvijas Republikas Saeima)

Datum: 22. 6. 2021

Dostupnost: curia.europa.eu

Panu B. byly $\mathrm{v}$ návaznosti na spáchání dopravních přestupků uloženy trestné body a v souladu s národní legislativou byl záznam o těchto bodech uložen do národního registru vozidel a řidičů. Tento registr byl veřejně přístupný $^{158}$ a další užití informací v něm uložených v principu nebylo omezeno. ${ }^{159}$ Předkládací soud konstatoval, že informace obsažené v registru jsou osobními údaji a zároveň, že trestné body jsou klasifikovány jako veřejně dostupné informace spadající pod působnost zákona o svobodném přístupu k informacím a lze je tedy opakovaně užít pro komerční i nekomerční účely. Na základě uvedených skutečností předkládací soud položil čtyři předběžné otázky: 1) zda se na zpracování informací o trestných bodech bude aplikovat čl. 10 GDPR, ${ }^{160}$ který upravuje „zpracování osobních údajů týkajících se odsouzení v trestních věcech a trestných činů či souvisejících bezpečnostních opatření“; 2) zda zásada integrity a důvěrnosti (čl. 5 odst. 1 písm. f) GDPR) musí být vykládána tak, že je členským státům zakázáno poskytnutí informací o trestných bodech a umožnění jejich dalšího užití; 3) zda čl. 5 odst. 1 písm. b), čl. 10 GDPR a čl. 1 odst. 2 písm. c) směrnice

\footnotetext{
157 Bod 43 anotovaného rozhodnutí.

158 Bod 32 anotovaného rozhodnutí.

159 Bod 38 anotovaného rozhodnutí.

${ }^{160}$ Nařízení Evropského parlamentu a Rady (EU) 2016/679 ze dne 27. 4. 2016 o ochraně fyzických osob v souvislosti se zpracováním osobních údajů a o volném pohybu těchto údajů a o zrušení směrnice 95/46/ES (obecné nařízení o ochraně osobních údajů).
} 
2003/98/ES (tzv. PSI směrnice) brání takové právní úpravě členského státu, která by umožnila zveřejnění a opětovné užití informací o trestných bodech; a konečně 4) zda „musí být zásada přednosti unijního práva a zásada právní jistoty vykládány $v$ tom smyslu, že by mohlo být umožněno sporné ustanovení uplatňovat a zachovat jeho právní účinky až do okamžiku, než Satversmes tiesa (Ústavní soud) $v$ dané věci s konečnou platností rozhodne?"161

Anotované rozhodnutí se zabývá vztahem dvou v základu kolidujících předpisů, a to GDPR, které zaručuje ochranu osobních údajů, a PSI směrnice, jejímž cílem je zajistit opětovné užití zveřejněných informací veřejného sektoru. V kontextu anotovaného př́ípadu jsou pak zásadní ustanovení čl. 5 a čl. 10 GDPR a čl. 1 odst. 2 písm. c) PSI Směrnice. ${ }^{162}$

Případě vyhodnocení první otázky se soud nejprve důkladně zabýval rozsahem věcné působnosti GDPR, zejména ve vztahu ke směrnici 2016/680 a možná zpracování ležící mimo aplikace práva EU. Následně i s odkazem na relevantní judikaturu ESLP stanovil, že „dopravní přstupky, které mohou vést $k$ připsání trestných bodů, spadají pod pojem 'trestné činy'

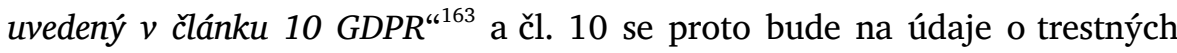
bodech vztahovat. Při vyhodnocení druhé otázky soud dospěl k závěru, že kombinace ustanovené čl. 5 odst. 1, čl. 6 odst. 1 písm. e) a čl. 10 GDPR vede $\mathrm{k}$ nutné interpretaci, že vnitrostátní právní úprava, která ukládá povinnost zveřejnit údaje o trestných bodech bez nutnosti prokázání zvláštního právního zájmu ze strany žadatele, odporuje požadavkům GDPR, a tedy evropskému právu. ${ }^{164}$ Třetí otázkou se soud zabýval již velmi stručně, když na základě předchozí argumentace dovodil, že není přípustná ani národní právní úprava, která by umožňovala př́stup $\mathrm{k}$ těmto údajům za účely opětovného užití. ${ }^{165}$ Konečně $\mathrm{v}$ odpovědi na čtvrtou otázku soud odmítl

\footnotetext{
161 Bod 53 anotovaného rozhodnutí.

162 Toto ustanovení uvádí, že směrnice se nepoužije na „[veřejnosti] př̌stupné části dokumentů, které obsahují osobní údaje, jejichž opakované použití bylo právně vymezeno jako jednání v rozporu s právními předpisy na ochranu osob $v$ souvislosti se zpracováním osobních údajü“. Obdobné ustanovení se pak nachází v podobě čl. 1 odst. 2 písm. h) i v nové směrnici EU č. 2019/1024 (open data směrnice), která PSI směrnici nahradila.

163 Bod 93 anotovaného rozhodnutí.

${ }^{164}$ Bod 122 anotovaného rozhodnutí.

${ }^{165}$ Bod 129 anotovaného rozhodnutí.
} 
možnost, že by s ohledem na zajištění právní jistoty bylo možné vykládat zásadu přednosti unijního práva tak, že by se ponechala $\mathrm{v}$ účinnosti právní úprava odporující unijnímu právu až do dne vyhlášení rozsudku předkládajícího ústavního soudu. ${ }^{166}$

Anotované rozhodnutí je první vlaštovkou přesněji vymezující možnost opětovného užití informací veřejného sektoru obsahující osobní údaje a staví na jistotu, že takto není možné dále užívat zvláštní kategorie osobních údajů.

Autor: JM

\section{EXCESIVNÍ ÚHRADA ZA ŽÁDOST O INFORMACE \\ $S$ PŘIHLÉDNUTÍM K MOŽNOSTI JE Z VELKÉ ČÁSTI ZÍSKAT STROJOVĚ}

Soud: $\quad$ Ústavní soud České republiky

Věc: $\quad$ III. ÚS 3339/20

Datum: $\quad 29.6 .2021$

Dostupnost: nalus.usoud.cz

Stěžovatel J.C. se dožadoval u Policejního Prezidia Policie ČR („žalovaný“) poskytnutí informací o trestných činech evidovaných za posledních pět let. ${ }^{167}$ Žalovaný vyhledávání informací žalovaný označil jako mimořádně rozsáhlé a stanovil úhradu ve výši 25827649 Kč. V odůvodnění uvádí, že vyhledání informací k jednomu trestnému činu zabere celkem 4 minuty a činů je evidováno $1543485 .^{168}$

Stěžovatel sdělení žalovaného napadl správní žalobou u Městského soudu v Praze („MSvP“). ${ }^{169}$ Namítal, že všechny údaje kromě jednoho může žalovaný strojově získat $\mathrm{z}$ evidence ${ }^{170}$. MSvP žalobu zamítl a čas na vyhle-

\footnotetext{
${ }^{166}$ Bod 137 anotovaného rozhodnutí.

${ }^{167}$ Body 2-4 anotovaného rozhodnutí.

${ }^{168}$ Bod 5 anotovaného rozhodnutí.

169 Bod 6 anotovaného rozhodnutí.

${ }^{170}$ Evidenčně statistický systém kriminality (ESSK)
} 
dání a následnou kontrolu informací označil za přiměřený. ${ }^{171}$ Stěžovatel podal kasační stížnost proti rozhodnutí1 ${ }^{172}$, kterou Nejvyšší správní soud („NSS“) zamítl. Stěžovatel namítal, že žalovaný se nepokusil vyhovět žádosti alespoň částečně. Tuto otázku NSS nepřezkoumal, nebot nebyla součástí původní žaloby, zároveň NSS souhlasí se způsobem kalkulace. ${ }^{173}$

Stěžovatel tvrdí, že subjekt má při žádosti o informace volit takovou možnost vyřízení, aby bylo možné informace alespoň z části poskytnout. Protože se tak nestalo, došlo k porušení práva na informace podle čl. 17 odst. 4 Listiny ${ }^{174} \cdot{ }^{175}$ Dále tvrdí, že došlo k porušení práva na soudní ochranu dle čl. 36 odst. 1 a 2 Listiny, když soudy neshledaly, že stanovený poplatek představuje ekonomickou bariéru a je excesivní. ${ }^{176}$

Čl. 17 Listiny zajištuje právo na informace a ukládá státním orgánům povinnost poskytovat informace o své činnosti. ${ }^{177} \S 17$ odst. 1 zákona o svobodném přístupu $\mathrm{k}$ informacím ${ }^{178}$ umožňuje $\mathrm{s}$ vyhledáním informací spojit úhradu, ${ }^{179}$ pokud je mimořádně rozsáhlé; tj. pokud se vymyká standardům běžné činnosti a představuje velkou časovou zátěž, samotné kritérium velkého množství údajů nestačíi. ${ }^{180}$

Ústavní soud konstatuje, že žalovaný má $\mathrm{k}$ dispozici evidenci, ze které lze jednoduše získat $7 \mathrm{z} 8$ požadovaných údajů. ${ }^{181}$ Vyčíslení úhrady je neopodstatněné ${ }^{182}$ a NSS je v rozporu se svou vlastní judikaturou. ${ }^{183}$ NSS se podle ÚS mýlí, když akceptoval argumentaci, že činnost je vymezena roz-

\footnotetext{
${ }^{171}$ Bod 8 anotovaného rozhodnutí.

${ }^{172}$ Bod 9 anotovaného rozhodnutí.

173 Body 10-14 anotovaného rozhodnutí.

${ }^{174}$ Listina základních práv a svobod, přijata usnesením č. 2/1993 předsednictva České národní rady jako součást ústavního pořádku České republiky

175 Bod 16 anotovaného rozhodnutí.

176 Body 17-19 anotovaného rozhodnutí.

${ }^{177}$ Bod 28 anotovaného rozhodnutí.

178 Zákon č. 106/1999 Sb., o svobodném přístupu k informacím

179 Bod 31 anotovaného rozhodnutí.

${ }^{180}$ Body 35-37 anotovaného rozhodnutí.

${ }^{181}$ Body 46-47 anotovaného rozhodnutí.

${ }^{182}$ Body 48-51 anotovaného rozhodnutí.

${ }^{183}$ Body 53-54 anotovaného rozhodnutí.
} 
sahem žádosti o informace; subjekt je povinen vyřídit žádost beze zbytku, nikoliv ale všechny informace stejným způsobem. ${ }^{184}$ Je úlohou povinných subjektů, aby hledaly způsoby, jak maximálně žádosti vyhovět. ${ }^{185} \mathrm{~V}$ rozhodované věci mohl subjekt žádosti částečně vyhovět a částečně stanovit úhradu za vyhledání jednoho z požadovaných údajů. ${ }^{186}$ Ústavní soud shrnuje, že NSS a MSvP uplatnily svou moc v rozporu s čl. 17 odst. 1, 4 a 5 Listiny a věc vrací $\mathrm{k}$ posouzení MSvP. ${ }^{187}$ Součástí nálezu je také disentní stanovisko. ${ }^{188}$

Nález stanoví, že je potřeba, aby povinný subjekt proaktivně stanovil přístup vyřízení žádosti o poskytnutí informací tak, aby mohly informace být v co největší míře poskytnuty.

Autorka: VPŽ

\section{PRÁVO NA PŘÍSTUP K INFORMACÍM O TECHNICKÝCH NORMÁCH}

Soud:

Soudní dvůr Evropské unie

Věc: $\mathrm{T}-185 / 19$

Datum: 14. 7.2021

Dostupnost: curia.europa.eu

Neziskové organizace Public Resource a Right to Know, které se zaměřují na zpřístupňování práva široké veřejnosti (dále jako „žalobkyně“), podaly v roce 2018 Evropské komisi žádost o přístup k dokumentům v držení Komise v souladu s nařízeními č. 1049/2001 a 1367/2006. Žádost se týkala čtyř harmonizovaných technických norem ohledně bezpečnosti hraček.

Komise na základě první odrážky čl. 4/2 nařízení č. 1049/2001 odmítla vyhovět této žádosti, přičemž žalobkyně následně podaly Komisi potvrzující

\footnotetext{
${ }^{184}$ Bod 57 anotovaného rozhodnutí.

${ }^{185}$ Body 60-61 anotovaného rozhodnutí.

${ }^{186}$ Bod 63 anotovaného rozhodnutí.

${ }^{187}$ Bod 73 anotovaného rozhodnutí.

${ }^{188}$ Odlišné stanovisko soudce Radovana Suchánka k nálezu sp. zn. III. ÚS 3339/20, Str. 19-21 anotovaného rozhodnutí.
} 
žádost, kterou Komise opětovně zamítla. Žalobkyně se tak s žádostí o zrušení opětovného rozhodnutí obrátily na Tribunál SDEU.

Žalobkyně před Tribunálem namítaly nesprávné právní posouzení skutkového stavu při uplatnění výjimky v čl. 4/2 nařízení č. 1049/2001, o přístupu veřejnosti $k$ dokumentům Evropského parlamentu, Rady a Komise. ${ }^{189}$

Článek 4/2 nařízení č. 1049/2001 stanovuje, že pokud neexistuje převažující veřejný zájem na zpř́istupnění, odepřou povinné orgány př́stup $\mathrm{k}$ dokumentu, pokud by takové zpřístupnění vedlo $\mathrm{k}$ ohrožení obchodních zájmů fyzické či právnické osoby.

Žalobkyně argumentovaly, že požadované harmonizované normy jsou součástí unijního práva a musí $\mathrm{k}$ nim tak být volný a bezplatný přístup. Tribunál se s touto argumentací ovšem neztotožnil ${ }^{190}$ a upozornil, že přestože cílem nařízení č. 1049/2001 je poskytnout veřejnosti co nejširší právo na přístup $\mathrm{k}$ dokumentům unijních orgánů, není toto právo absolutní a bezbřehé, přičemž odkázal na výjimku v čl. 4/2 téhož nařízení. ${ }^{191}$ Dále pak soud připomenul, že harmonizované normy mohou ve světle předchozí judikatury ${ }^{192}$ naplňovat definici autorského díla a požadované prahové hodnoty originality. ${ }^{193}$ Jejich ochrana je tak bez pochyb součástí obchodních zájmů CEN, a přestože CEN při vypracovávání těchto harmonizovaných norem jedná ve veřejném zájmu, z ustanovení upravujících evropský systém normalizace nijak nevyplývá, že by CEN jednal jako orgán veřejné moci plnící veřejné funkce, které nepodléhají žádnému obchodnímu zájmu. ${ }^{194}$ Nic se tak nemění na jeho povaze soukromoprávní entity, jejíž obchodní zájmy jsou hodny ochrany a pro jejichž porušení by zde bylo nutné nalézt převažující veřejný zájem. ${ }^{195}$ Soud však potvrdil správnost postupu

\footnotetext{
189 Body 24-26 anotovaného rozhodnutí.

190 Bod 27 anotovaného rozhodnutí.

191 Body 29-37 anotovaného rozhodnutí.

${ }^{192}$ Viz rozsudek ze dne 11. června 2020, Brompton Bicycle, C-833/18, EU:C:2020:461, bod 23 a citovaná judikatura; a rozsudek ze dne 27. ř́jna 2016, James Elliott Construction (C613/14, EU:C:2016:821).

193 Body 46-55 a dále 56 až 60 anotovaného rozhodnutí.

194 Body 69-73 anotovaného rozhodnutí.

195 Tamtéž.
} 
Komise i v případě neexistence veřejného zájmu (a to včetně podkategorií přístupu $\mathrm{k}$ právním předpisům ${ }^{196} \mathrm{i}$ informací ohledně emisí do životního prostředí ${ }^{197}$ ) na zpřístupnění a znovu připomenul, že i když je Komise povinna uvést důvody pro uplatnění jedné z výjimek z práva na přístup dle nařízení 1049/2001, není povinna poskytnout informace jdoucí nad rámec toho, co je nezbytné $\mathrm{k}$ tomu, aby bylo možné přezkoumat legalitu rozhodnutí. ${ }^{198} \mathrm{Na}$ základě těchto skutečností tak Tribunál žalobu v plném rozsahu zamítl. ${ }^{199}$

Autor: JV

\section{OSTATNí}

\section{VENDOR LOCK-IN GENERÁLNÍHO FINANČNÍHO ŘEDITELSTVÍ}

Soud:

Krajský soud v Brně

Č. j.:

29 Af $27 / 2018-93$

Datum:

31. 5.2021

Dostupnost: uohs.cz

Krajský soud v Brně se v předmětném rozsudku zabýval žalobou podanou Českou republikou - Generálním finančním ředitelstvím, proti rozhodnutí předsedy Úřadu o ochraně hospodářské soutěže („ÚOHS“). Žalobce, jakožto zadavatel, při zadávání veřejné zakázky „ADIS - Hot-line, konzultační služby a technická podpora v roce 2016“ využil institutu jednacího řízení bez uveřejnění („JŘBU“). Žalobce se tímto postupem dle rozhodnutí ÚOHS dopustil přestupku, nebot’ nedodržel podmínky pro využití zmíněného druhu řízení. Závěr ÚOHS byl pak potvrzen i předsedou tohoto úřadu v rámci rozhodnutí o rozkladu. ${ }^{200}$

\footnotetext{
${ }^{196}$ V čemž navazují na rozsudek ze dne 27. října 2016, James Elliott Construction (C-613/14, EU:C:2016:821), viz body 97-107 anotovaného rozhodnutí.

197 Body 113-119 a 121-129 anotovaného rozhodnutí.

${ }^{198}$ Body 86-91 anotovaného rozhodnutí.

${ }^{199}$ Bod 130 anotovaného rozhodnutí.

${ }^{200}$ Body 1-7 anotovaného rozhodnutí.
} 
Předmětem sporu před soudem byla právě otázka, zda žalobce naplnil podmínky pro využití JŘBU. ${ }^{201}$

Využití JŘBU je možné, na rozdíl od otevřeného a užšího řízení, jen za naplnění taxativně vyjmenovaných podmínek (nebot' je s ním mimo jiné spojeno omezení hospodářské soutěže). ${ }^{202}$ Jednou $\mathrm{z}$ nich je, resp. v tomto konkrétním znění byla, i skutečnost, že veřejná zakázka „může být splněna z technických či uměleckých důvodů, z důvodu ochrany výhradních práv nebo z dưvodi̊ vyplývajících ze zvláštního právního préedpisu pouze určitým dodavatelem“ “ ${ }^{203}$ Právě vznik této situace, konkrétně potřebu ochrany výhradních (zde autorských) práv, žalobce v předmětném sporu deklaruje. ${ }^{204}$ Tuto podmínku pro využití JŘBU je však možné využít pouze tehdy, pokud nejde využít jiného postupu (na straně dodavatele vzniká exkluzivita) a zároveň tehdy, nejedná-li se o exkluzivitu zaviněnou zadavatelem. To vše přitom musí zadavatel prokázat. Posouzení toho, zda daná situace vznikla vinou zadavatele, lze označit za stěžejní součást anotovaného rozsudku.

Soud ze skutkových okolností mimo jiné dovodil, že si žalobcův předchůdce musel být vědom budoucí potřeby plnění ohledně technické a konzultační podpory informačního IS ADIS, a to již v době uzavření smlouvy, na kterou předmětná veřejná zakázka navazuje. ${ }^{205}$ Při pořizování původního plnění si tak měl vymínit dostatečná oprávnění a předejít tak situaci, kdy je omezena hospodářská soutěž (vendor lock-inu). To však neučinil. $\mathrm{Z}$ tohoto důvodu nebyla splněna jedna z kumulativních podmínek pro využití JŘBU při zadávání „navazující zakázky“, resp. se splnění této podmínky zadavateli nepovedlo prokázat. ${ }^{206}$

\footnotetext{
201 Bod 31 anotovaného rozhodnutí.

${ }^{202}$ Viz § 23 již neúčinného zákona č. 137/2006 Sb., o veřejných zakázkách, kterým se zadavatel v daném případě řídil, nebo § 63 nyní účinného zákona č. 134/2016 Sb., o zadávání veřejných zakázek.

${ }^{203}$ Viz § 23 odst. 4 již neúčinného zákona č. 137/2006 Sb., o veřejných zakázkách, kterým se zadavatel v daném prrípadě řídil, nebo § 63 odst. 3 nyní účinného zákona č. 134/2016 Sb., o zadávání veřejných zakázek.

${ }^{204}$ Srov. odst. 33 anotovaného rozhodnutí.

205 Bod 50 anotovaného rozhodnutí.

${ }^{206}$ Body 30-60 anotovaného rozhodnutí.
} 
Předmětný rozsudek potvrzuje soudy zavedený př́stup, který je nyní navíc i přímo stanoven zákonem, že některé podmínky pro využití JŘBU je možné využít jen pro řešení zadavatelem nezaviněné exkluzivity. ${ }^{207}$

Autor: JS

Toto dílo lze užít v souladu s licenčními podmínkami Creative Commons BY-SA 4.0 International (http://creativecommons.org/licenses/by-sa/4.0/legalcode).

${ }^{207}$ Ve vztahu k již neúčinnému zákonu č. 137/2006 Sb., o veřejných zakázkách, viz např. rozsudek Nejvyššího správního soudu ze dne 11. 1. 2013, č. j. 5 Afs 42/2012 - 53; dále viz § 63 odst. 4 zákona č. 134/2016 Sb., o zadávání veřejných zakázek. 